\title{
Removal of Heavy Metals from Leachate Using Electro-Assisted Phytoremediation (EAPR) and Up-Take by Water Hyacinth (Eichornia crassipes)
}

\author{
Rudy Syah Putra ${ }^{1,2,}$ and Febby Yulia Hastika ${ }^{1}$ \\ ${ }^{1}$ Department of Chemistry, Faculty of Mathematics and Natural Sciences, Universitas Islam Indonesia, \\ J. Kaliurang Km. 14, Yogyakarta 55584, Indonesia \\ ${ }^{2}$ Environmental Remediation Research Group, Faculty of Mathematics and Natural Sciences, Universitas Islam Indonesia, \\ Jl. Kaliurang Km. 14, Yogyakarta 55584, Indonesia
}

Received October 29, 2017; Accepted December 14, 2017

\begin{abstract}
The garbage disposal management using landfill system produces an unpleasant odor of wastewater (i.e. leachate) which can disrupt the groundwater equilibrium in the rainy season. The combination of electro-assisted and phytoremediation which is hereinafter referred as Electro-Assisted Phytoremediation (EAPR) for removal of heavy metals from leachate has been demonstrated in a laboratory-scale experiment. A batch reactor setting was used to evaluate the potential removal and uptake of heavy metals ( $\mathrm{Fe}, \mathrm{Cu}, \mathrm{Cd}$, and $\mathrm{Pb}$ ) concentration by water hyacinth (Eichornia crassipes) in the aquatic environment. An EAPR system was carried out for $11 \mathrm{~d}$ using constant voltage of $2 \mathrm{~V}$. The results showed that the heavy metals concentration in the leachate decreased significantly for $\mathrm{Cu}, \mathrm{Fe}, \mathrm{Cd}$ and $\mathrm{Pb}$ metals from their initial concentration. The EAPR process could reduce as much as 77.8, 22, 31.6 and $30.0 \%$, respectively for $\mathrm{Fe}, \mathrm{Cu}, \mathrm{Cd}$, and $\mathrm{Pb}$. Decreasing of heavy metals was followed by decreasing of TDS, electrical conductivity but increased DO concentration. Chlorophyll content in a treated plant with EAPR system showed that the water hyacinth could cope with the stress condition meanwhile accumulated high heavy metal concentration from the leachate.
\end{abstract}

Keywords: EAPR; heavy metals; leachate; water hyacinth

\section{ABSTRAK}

Pengolahan sampah terpadu dengan metode landfill masih banyak dilakukan karena relatif murah. Kekurangan dalam metode ini adalah menghasilkan limbah cair berwarna hitam, berbau menyengat dan dapat mengakibatkan pencemaran lingkungan yang disebut dengan air lindi. Gabungan metode bantuan-listrik dan fitoremediasi yang kemudian disebut Electro-Assisted Phytoremediation (EAPR) telah digunakan untuk remediasi logam berat pada air lindi yang dilakukan dalam skala laboratorium. Rancangan reaktor jenis batch digunakan untuk evaluasi kemampuan sistim remediasi logam berat ( $\mathrm{Fe}, \mathrm{Cu}, \mathrm{Cd}$ dan $\mathrm{Pb}$ ) menggunakan tanaman eceng gondok (Eichornia crassipes) di lingkungan perairan. Proses EAPR dilakukan selama 11 hari menggunakan tegangan konstan sebesar $2 \mathrm{~V}$. Hasil penelitian menunjukkan bahwa konsentrasi logam berat pada air lindi mengalami penurunan yang signifikan untuk logam $\mathrm{Cu}, \mathrm{Fe}, \mathrm{Cd}$ dan $\mathrm{Pb}$ dari konsentrasi awal. Proses EAPR mampu mengurangi konsentrasi logam berat masing-masing sebesar 77,8, 22, 31,6 dan 30,0\% berturut-turut untuk logam $\mathrm{Fe}, \mathrm{Cu}, \mathrm{Cd}$ dan $\mathrm{Pb}$. Penurunan konsentrasi logam berat diikuti dengan penurunan angka TDS dan konduktivitas listrik, akan tetapi terjadi peningkatan konsentrasi DO. Kandungan klorofil pada tanaman yang menyerap logam berat pada sistem EAPR menunjukkan bahwa tanaman eceng gondok mampu mengatasi kondisi stress akibat lingkungan toksik sekaligus mampu menyerap konsentrasi logam berat yang tinggi dari air lindi.

Kata Kunci: EAPR; logam berat; eceng gondok; air lindi

\section{INTRODUCTION}

Increasingly affluent lifestyle, continuing industrial and commercial growth in many countries around the world in the past decade has been accompanied by a rapid increase in both the municipal and industrial solid waste production. Municipal solid waste generation continues to grow both in per capita and overall terms. The landfilling is an attractive method for the municipal solid waste management due to economic consideration [1], so it is especially applicable for developing countries like Indonesia. Solid waste disposal is carried out in several ways, as landfills, controlled dumps and in the worst cases, open-pit

* Corresponding author.

DOI: 10.22146/ijc.29713

Email address : rudy.syahputra@uii.ac.id 
dumps with environmental problems due to water (surface and underground) and soil contaminated.

The main pollution issue associated with landfill sites are the production of potentially explosive gases and liquid leachate. Leachate emission from landfill sites is growing concern, primarily due to their toxic impact when released unchecked into the environment, and the potential for landfill sites to generate leachate for many hundreds of years following closure [2]. The leachate has a dark color, bad smell, and high organic and nitrogen loads. Leachate may carry immiscible liquids (e.g., oil), small particulates (suspended solids) and a range of organism (e.g., bacteria and viruses) [3]. Leachate may also contain a large amount of organic matter (biodegradable, but also refractory to biodegradation). Treatment for leachate is difficult because leachate contained heavy metals, humic substances, recalcitrant compounds and chlorinated organic and inorganic salt [4-7].

For leachate treatment using conventional methods, it can be classified into three major groups: (a) leachate transfer: recycling and combined treatment with domestic sewage, (b) biodegradation: aerobic and anaerobic processes and (c) chemical and physical methods: chemical oxidation, adsorption, chemical precipitation, coagulation/flocculation, sedimentation/flotation and air stripping [8]. However, with the continuous hardening of the discharge standards in most countries and the aging of landfill sites with more and more stabilized leachates, conventional treatments (biological or physicochemical) are not sufficient anymore to reach the level of purification needed to fully reduce the negative impact of landfill leachates on the environment. It implies that new alternatives treatment must be proposed.

Phytoremediation is the use of plant and plant process to remove, degrade, or render harmless hazardous materials present in the soil or groundwater [9]. This emerging technology may offer a more costeffective, non-intrusive and safe alternative to conventional water clean-up techniques. However, its application is limited to surface contamination only, because the clean-up depth is strictly determined by the length of the plant roots. It is a passive technology in terms of contaminant transport, the movement of contaminants in the water is induced exclusively by slow plant root suction and thus the efficiency of removal of contaminants depends on the extension of the plant roots in the water surface [10].

The combination of electro-assisted and phytoremediation which is hereinafter referred as Electro-Assisted Phytoremediation (EAPR) can be an alternative to overcome the problems of waste that pollute the environment. The EAPR is an electrokinetic process with the incorporation of phytoremediation. In the EAPR system, the key element is electrokinetic/electromigration mobilization of metal ions which increased metal ion availability to the plant root and thus plant metal uptake and subsequent extraction by phytoremediation [11]. In the EAPR system, heavy metal ions were transported to the roots zone by electro-migration and deposited to the shoot system through the adsorption process [12]. The plant commonly employed for phytoremediation has a high biomass plant, rapid growth, and high hyper accumulation, such as Vetiver grass (Vetiveria zizaniodes) and Indian mustard (Brassica juncea).

The applications of EAPR process in aqueous media was first reported by $\mathrm{Bi}$ et al. [13] using lettuce plants (Lactuta sativa) grown in a medium containing $\mathrm{Cd}$. Based on research conducted by Putra et al. [14], the application of EAPR in the removal of heavy metal from wastewater using water hyacinth had able to reduce $\mathrm{Pb}$ by $49 \%$ and $\mathrm{Cu}$ by $58 \%$ when compared with phytoremediation that could only able to reduce $\mathrm{Pb}$ by $32 \%$ and $\mathrm{Cu}$ by $39 \%$. In addition, the enhancement of electrocoagulation on EAPR process using water hyacinth could reduce the concentration of $\mathrm{Pb}$ by $74.4 \%$ and $\mathrm{Cu}$ up to $60.1 \%$ from the initial concentration of heavy metal in chemical laboratory wastewater [15]. Therefore, the ability of the EPAR process to reduce the heavy metal concentration depends on the initial heavy metal concentration and the easy plant grows in the toxic aquatic media. Although from previous results have verified the enhancement of heavy metal uptake by plants after the application of electrical field on the phytoremediation, the $\mathrm{pH}$ reduction had been an un-favorable parameter limiting the plant growth [11] and extreme toxicant concentration in the leachate would reduce plant growth under the DC field application. Thus several aspects of EAPR system still need to be adjusted when using the EAPR process on the removal of heavy metal from leachate liquid.

The objective of this study was to evaluate the enhancement process of phytoremediation by the application of electro-assisted phytoremediation (EAPR) for the treatment of leachate using water hyacinth (Eichornia crassipes) as an accumulator species. The effectiveness of these process on the leachate treatment was evaluated by using the following parameters, (i) heavy metals concentration (i.e. $\mathrm{Fe}, \mathrm{Cu}, \mathrm{Cd}$ and $\mathrm{Pb}$ ) in the solution and plant including the bioaccumulation coefficient (BC) and translocation factor (TF), (ii) environment parameters e.g. pH, DO, TDS and electrical conductivity and (iii) Plant stress was also monitored including the chlorophyll content (i.e. chlorophyll $\mathrm{a} / \mathrm{b}$ ratio and total chlorophyll). 


\section{EXPERIMENTAL SECTION}

\section{Leachate Liquid Sample}

The leachate liquid was taken from Integrated Waste Disposal Management (Tempat Pengolahan Sampah Terpadu-TPST) plant at Piyungan, Bantul, Yogyakarta, Indonesia. In the plant, there were three reservoirs namely young leachate in the inlet, mature leachate which already added by PAC (Poly Aluminum Chloride) as a coagulant in the processed tank and readily leachate to discard in the outlet. The young leachate was tested in this study and diluted 20 times using deionized water before being used in EAPR process. All samples were measured the DO, TDS, pH, electric conductivity $(E C)$ and temperature, respectively.

\section{EAPR Set-up}

Water hyacinth (Eichhornia crassipes) was collected from waterways around Sleman district of Yogyakarta province, Indonesia. Plants then washed to remove debris before being placed in the trays containing fresh water and transferred to growth chamber in which the plants were allowed to acclimatize for $3 \mathrm{~d}$ in half-strength Hoagland solution. The modified half-strength Hoagland solution was prepared according to a reported paper by Putra et al. [12]. The solution mixing contains $0.0676 \mathrm{~g}$ of $\mathrm{KH}_{2} \mathrm{PO}_{4}, 0.253 \mathrm{~g}$ of $\mathrm{KNO}_{3}$, $0.59 \mathrm{~g}$ of $\mathrm{Ca}\left(\mathrm{NO}_{3}\right)_{2} \cdot 4 \mathrm{H}_{2} \mathrm{O}$, and $0.20 \mathrm{~g}$ of $\mathrm{MgCl}_{2} \cdot 6 \mathrm{H}_{2} \mathrm{O}$ in 1 $L$ solution. The plant was grown in the EAPR reactor with the dimension of $40(\mathrm{~L}) \mathrm{cm} \times 25(\mathrm{~W}) \mathrm{cm} \times 35(\mathrm{H}) \mathrm{cm}$. Periodically, the solution was sampled and measured for $\mathrm{pH}$, TDS, Conductivity and DO during the $11 \mathrm{~d}$ growth period. Aliquots were withdrawn from the reactor by 50 $\mathrm{mL}$, added few drops of $\mathrm{HNO}_{3}$ before measurement of heavy metal using flame-AAS (Perkin-Elmer, PinAAcle
900T, USA). The reactor was set up with cathode pot electrode made of the combined of stainless steel U316 rod $(30 \mathrm{~cm} \mathrm{(L)} \times 1 \mathrm{~cm}(\mathrm{~W})$, thickness $3 \mathrm{~mm})$ and net wire $(30 \mathrm{~cm}(\mathrm{~L}) \times 20 \mathrm{~cm}(\mathrm{~W}), 10$ messes). Titanium rod was used as anode (95\% Ti, Ø $6 \mathrm{~mm} \times 30 \mathrm{~cm}(\mathrm{~L})$. The system was carried out at a constant voltage of 2.0 V. The light source was provided from $40 \mathrm{~W}$ of fluorescent tubes and $20 \mathrm{~W}$ of incandescent lamps which were controlled by an intra-matrix timer to provide 12/12 h light/dark cycle. Fig. 1 shows the EAPR system set up and designed cathode-pot electrode used in the experiment.

\section{Plant Analysis}

Directly after the completion of the experiment, plants were harvested, washed thoroughly with running tap water, weighed and separated into shoot and root. In this study, water hyacinth has no true leaves of the plant; therefore total metal concentration was measured in the root and whole upper part including leaves that was assumed as shoot part. The shoot and root were cut into small pieces, dried for $4 \mathrm{~d}$ at $80^{\circ} \mathrm{C}$. Approximately $100 \mathrm{mg}$ of sample were digested in 5 $\mathrm{mL} \mathrm{HNO}_{3}$ for overnight and then adjusted to a volume of $25 \mathrm{~mL}$ by deionized water. The heavy metals $(\mathrm{Cu}$, $\mathrm{Fe}, \mathrm{Cd}$ and $\mathrm{Pb}$ ) concentration in the acid extract was determined by a flame-AAS (Perkin-Elmer, PinAAcle 900T, USA). Plants were observed and monitored every day to take note of changes in appearance. Chlorophyll content of plants was measured according to the method reported by Moran and Poranth [16], briefly, procedures were as follow: a sample of $9 \mathrm{~g}$ of the shoot was cut into $0.5 \mathrm{~cm}$ segments and incubated in acetone for $24 \mathrm{~h}$ at $4{ }^{\circ} \mathrm{C}$ in the dark room. The absorbance of the solution was measured with a spectrophotometer at $\lambda 654$ and $\lambda 663 \mathrm{~nm}$. Chlorophyll
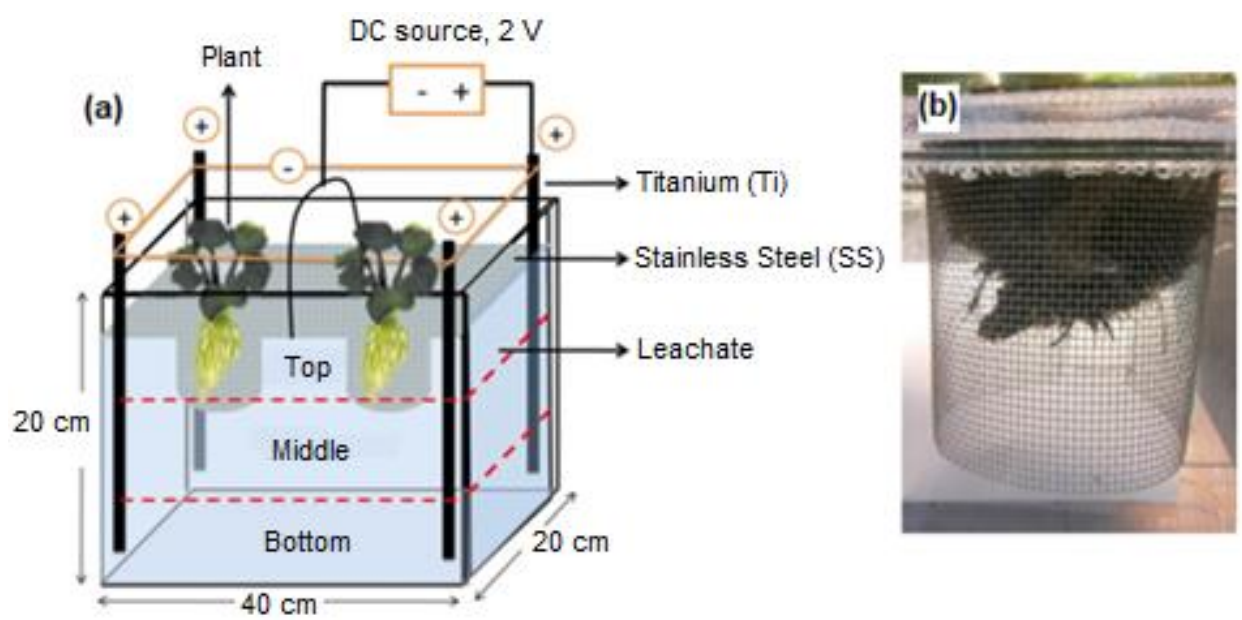

Fig 1. EAPR set up for experiment and the sampling points in the reactor. Schematic diagram of the reactor (a) and designed cathode-pot (b) used in the experiment 

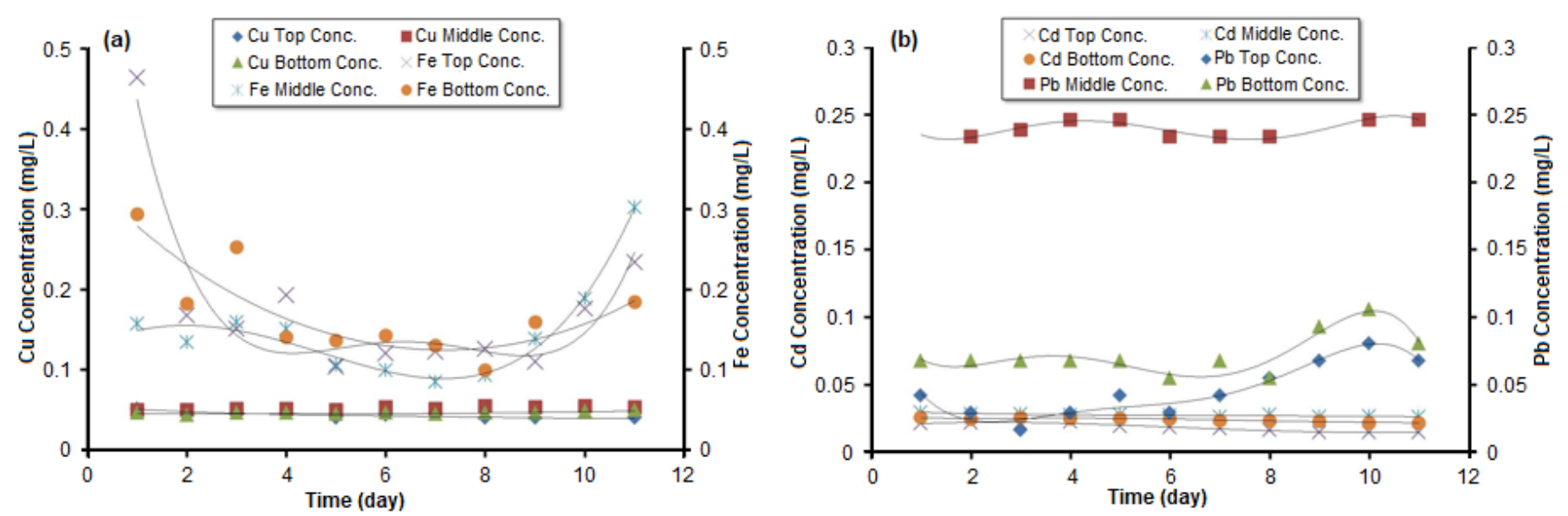

Fig 2. Profiles of electromigration of $\mathrm{Fe}, \mathrm{Cu}$ ions $(\mathrm{a})$ and $\mathrm{Cd}, \mathrm{Pb}$ ions (b) in the solution using cathode-pot electrode in the EAPR system

concentration $(\mathrm{mg} / \mathrm{mL})$ was calculated by using the following equations:

$[\mathrm{Chl} \mathrm{a}]=[12.7 \times$ Abs $663 \mathrm{~nm}]-[2.69 \times$ Abs $645 \mathrm{~nm}]$ $[\mathrm{Chl} \mathrm{b}]=[22.9 \times$ Abs $645 \mathrm{~nm}]-[4.68 \times$ Abs $663 \mathrm{~nm}]$

[Chl total $]=[8.02 \times$ Abs $663 \mathrm{~nm}]+[20.2 \times$ Abs $645 \mathrm{~nm}]$

\section{RESULT AND DISCUSSION}

\section{Evaluation of Cathode-pot Electrode on the EAPR}

Periodically solution was sampling from EAPR reactor at three level points (see Fig. 1) to evaluate the effectiveness of electromigration of heavy metals (Fe, $\mathrm{Cu}, \mathrm{Cd}$ and $\mathrm{Pb}$ ) ions once a day during the $11 \mathrm{~d}$ process. Sampling points in the EAPR reactor were in the bottom, middle, and top point which closest to the surface of the cathode-pot area. Fig. $2 a$ and $2 b$ show the results of electromigration process of heavy metals ions in the EAPR system. Fig. 2a shows at the top point, $\mathrm{Fe}$ ions concentration decreased from the initial concentration of $0.463 \mathrm{mg} / \mathrm{L}$ to $0.103 \mathrm{mg} / \mathrm{L}(77.8 \%)$, whereas $\mathrm{Cu}$ concentration decreased from the initial concentration of $0.507 \mathrm{mg} / \mathrm{L}$ to $0.395 \mathrm{mg} / \mathrm{L}(22 \%)$. Electromigration of $\mathrm{Fe}$ and $\mathrm{Cu}$ ions in the EAPR system showed that the ions move from the bottom to the top point of the reactor. Fig. $2 \mathrm{~b}$ shows the electromigration of $\mathrm{Cd}$ and $\mathrm{Pb}$, the concentration of $\mathrm{Pb}$ decreased from $0.042 \mathrm{mg} / \mathrm{L}$ to 0.029 $\mathrm{mg} / \mathrm{L}(30 \%)$ while, $\mathrm{Cd}$ concentration decreased from $0.021 \mathrm{mg} / \mathrm{L}$ to $0.015 \mathrm{mg} / \mathrm{L}$ (31.6\%). However, there were the anomaly concentrations at the middle point of the reactor. When $\mathrm{Pb}$ and $\mathrm{Cd}$ ions in solution migrated to the top point which closest to the cathode-pot area, $\mathrm{OH}^{-}$ generated in the cathode would bond with $\mathrm{Pb}$ and $\mathrm{Cd}$ ions and then formed a hydroxide as $\mathrm{Pb}(\mathrm{OH})_{2}$ and $\mathrm{Cd}(\mathrm{OH})_{2}$ as a precipitated compound. Since the flocculants size in the process relatively small and the ions $\mathrm{H}^{+}$generated in the anode made the flocculants difficulties to settle completely in the bottom of the reactor, the flocculants gathered at the middle of the reactor affect the concentration of $\mathrm{Pb}$ and $\mathrm{Cd}$ were high in the middle point of EAPR reactor. Those result showed that the metal ions were effectively transported toward the top point which closest to the plant roots using a designed cathode-pot electrode. In this study, even though the removal of $\mathrm{Cu}, \mathrm{Pb}$ and $\mathrm{Cd}$ metals was relatively low percentage, but the concentration has already achieved the permissible of limit reducing concentration of heavy metals according to Ministry of Environment No. 5/2014 regarding the wastewater quality standard and No. 59/2016 regarding the leachate quality standard of the Republic of Indonesia, which were $2.0,0.1$ and $0.1 \mathrm{mg} / \mathrm{L}$, respectively for $\mathrm{Cu}$, $\mathrm{Pb}$ and $\mathrm{Cd}$ concentration.

\section{Heavy Metal Concentration in the Water Hyacinth (Eichhornia crassipes)}

To evaluate the accumulation capacity of the studied plant, the heavy metals concentration were measured in the roots and shoot of a plant grown on the EAPR system and the result was showed in Fig. 3. Copper and iron uptake by water hyacinth were mostly accumulated in the shooting part, while for lead and cadmium was dominantly in the root part. The efficiency of phytoremediation can be quantified by calculating the translocation factor (TF) which was defined as the ratio of metal concentration in the upper part of plant to that in the roots [17] and bioaccumulation coefficient (BC) which was defined as the ratio of metal concentration in root tissue to initial metal concentration in solution [18]. Therefore, the translocation factor indicates the efficiency of the plant in translocation the accumulated metal from its roots to shoots, while the bioaccumulation coefficient was a calculation to check the adsorption of heavy metals from solution to the root system. $\mathrm{Pb}$ was the most widely 


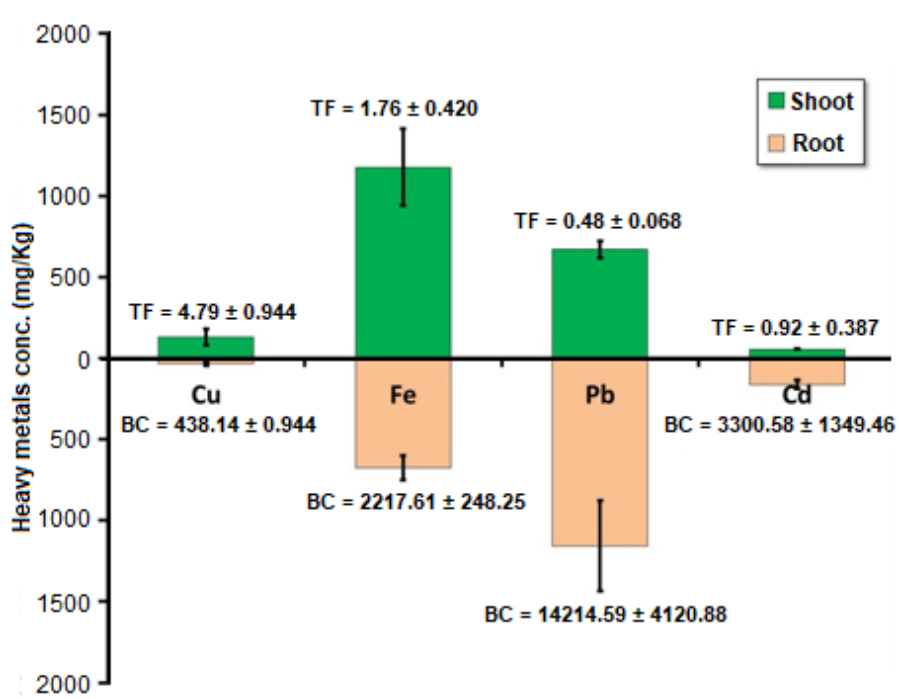

Fig 3. The accumulation of $\mathrm{Cu}, \mathrm{Fe}, \mathrm{Pb}$ and $\mathrm{Cd}$ metals uptake by water hyacinth (Eichhornia crassipes) in the EAPR system

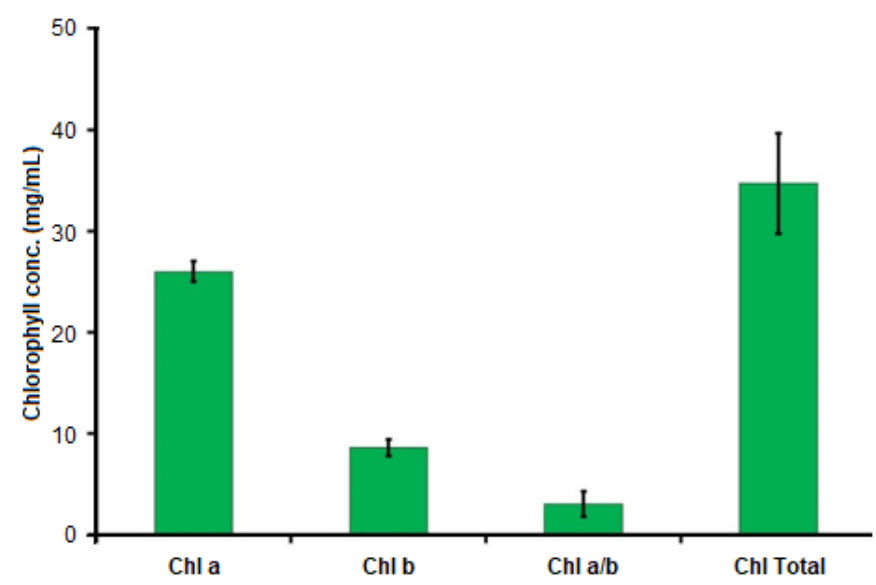

Fig 4. Profile of plant chlorophyll after EAPR process

absorbed heavy metal in the root part of a plan, indicating by the high $\mathrm{BC}$ value of $\mathrm{Pb}$ among the metals, but $\mathrm{Cu}$ was the least accumulated in the root part, indicating by the smallest $\mathrm{BC}$ value. However, the translocation of $\mathrm{Cu}$ from the root to the shoot in this study was higher than the other heavy metals.

\section{Stress Tolerance in Water Hyacinth (Eichornia crassipes)}

Measurement of physiological characters such as chlorophyll was one approach to study the effects of water shortages on growth and yield, as this parameter is closely related to the rate of photosynthesis [19].Total chlorophyll contents and the $\mathrm{Chl} a / b$ ratio are the parameters for photosynthetic activity and also often used as the indicators of stress in plants grown on environmental contaminants [12]. These parameters have been used for detecting and assessing the exposure of plants to environmental contaminants [2021]. Fig. 4 shows the concentration of total chlorophyll was $34.7 \mathrm{mg} / \mathrm{L}$ and $\mathrm{Chl}$ a/b ratio was 3.02 . Compared with the control plants (i.e. water hyacinth) grown in fresh water, total chlorophyll content and $\mathrm{Chl}$ a/b ratio were around $45-47 \mathrm{mg} / \mathrm{mL}$ and $0.86-1.82 \mathrm{mg} / \mathrm{mL}$, respectively [22]. Therefore in this study, relatively low total chlorophyll content and $\mathrm{Chl} a / b$ ratio have indicated that the plants were being exposed to less toxic chemical stressing as well. The same results for EAPR system have been previously reported according to Putra et al. $[12,15]$. The visual characteristic of water hyacinth (Eichornia crassipes) was observed and monitored every day to take a note of changes in appearance. The plant grown in the EAPR system did not show any significant phytotoxic symptoms (e.g. discoloration, pigmentation, yellowing and withering), suggesting higher tolerant of the plant to the heavy metal concentration. Therefore, a metal pollutant in the leachate does not affect the production of chlorophyll in the plant. In addition, total chlorophyll content showed that the application of electric current in EAPR system does not affect the production of chlorophyll by leaves. Based on these results, it was concluded that the enhancement of phytoremediation by electro-assisted system did not imply to disrupt the photosynthesis in the plant tissues.

\section{Environmental Parameters}

The total dissolved solids (TDS), electrical conductivity (EC), $\mathrm{pH}$ and dissolved oxygen (DO) concentration of the leachate were measured before and during the EAPR process. Fig. 5 a shows the TDS concentration and EC during $11 \mathrm{~d}$ process has not decreased significantly. The concentration of TDS decreased from $395 \mathrm{mg} / \mathrm{L}$ to $371 \mathrm{mg} / \mathrm{L}$ whereas, the EC decrease from $774 \mu \mathrm{S} / \mathrm{cm}$ to $743 \mu \mathrm{S} / \mathrm{cm}$. The constituent of solutes in TDS are either inorganic, including cations (sodium, calcium, magnesium, and potassium), or anions (carbonates, nitrates, bicarbonate, and chloride, sulphate). Electrical conductivity (property closely related to TDS) of solutions depends upon the concentrations and mobility of these ions. Electrical Conductivity is a surrogate measure of total dissolved solids with established stable relationship [23]. Fig. 5b shows the profile of $\mathrm{pH}$ and dissolved oxygen (DO) concentration in the solution increased during EAPR process. Photosynthesis by aquatic plants during the daylight removes carbon dioxide $\left(\mathrm{CO}_{2}\right)$ from the medium hence $\mathrm{pH}$ would increase [24]. On the other hand, the increase of $\mathrm{pH}$ in solution because of the continuous hydroxyl ion production occurs at the cathode. The factor 

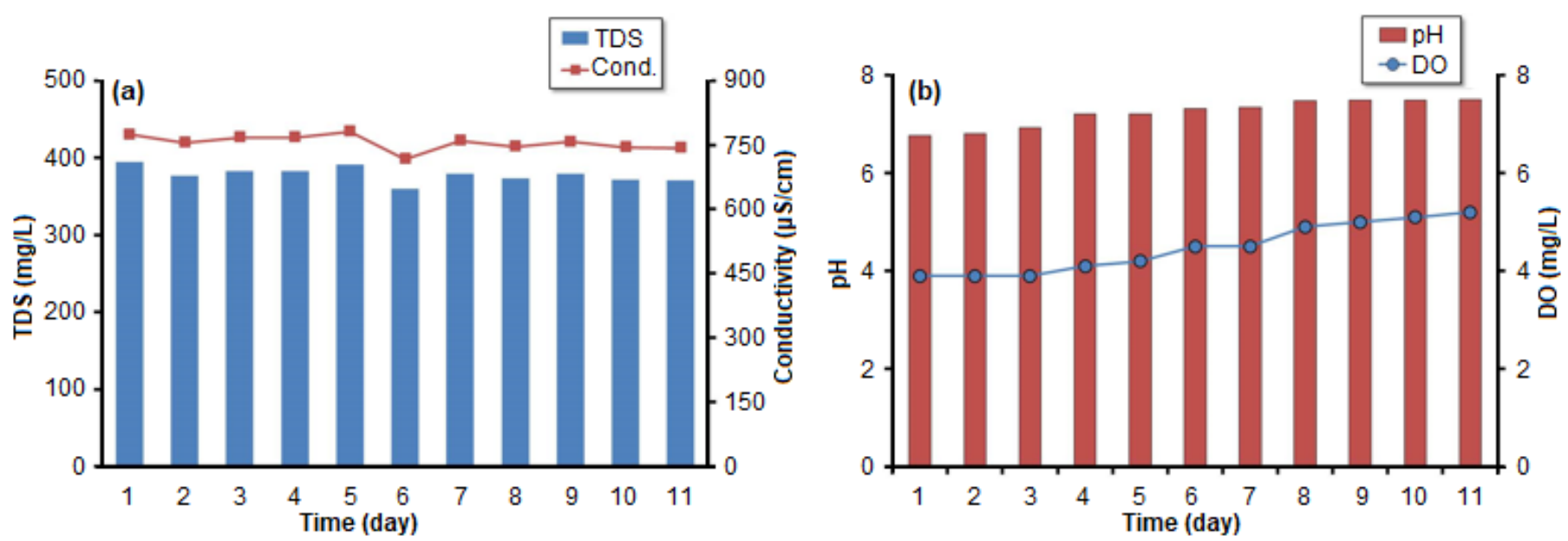

Fig 5. Profile of TDS concentration and EC (a) and $\mathrm{pH}$ and $\mathrm{DO}$ concentration (b) in the solution during the EAPR process

of increased DO concentration was an oxidation reaction occurred at the anode. The principle of producing electrolyzed water was shown in the following reaction [25]:

Anode: $2 \mathrm{H}_{2} \mathrm{O} \rightarrow 4 \mathrm{H}^{+}+\mathrm{O}_{2}+4 \mathrm{e}^{-}$

Cathode: $2 \mathrm{H}_{2} \mathrm{O}+2 \mathrm{e}^{-} \rightarrow 2 \mathrm{OH}^{-}+\mathrm{H}_{2}$

\section{CONCLUSION}

In conclusion, the result confirmed that the ElectroAssisted Phytoremediation (EAPR) process could remove significantly the heavy metals concentration in the leachate from the initial concentration of $0.463 \mathrm{mg} / \mathrm{L}$ to $0.103 \mathrm{mg} / \mathrm{L}(77.8 \%), 0.507 \mathrm{mg} / \mathrm{L}$ to $0.395 \mathrm{mg} / \mathrm{L}(22 \%)$, $0.042 \mathrm{mg} / \mathrm{L}$ to $0.029 \mathrm{mg} / \mathrm{L}(30 \%), 0.021 \mathrm{mg} / \mathrm{L}$ to 0.015 $\mathrm{mg} / \mathrm{L}(31.6 \%)$, respectively for $\mathrm{Fe}, \mathrm{Cu}, \mathrm{Pb}$ and $\mathrm{Cd}$ ions. Generally, the heavy metal accumulation in the plant shows that copper and iron uptake by water hyacinth was dominant in the shoot part, meanwhile for lead and cadmium was in the root part. Water hyacinths (Eichornia crassipes) was able to grow in leachate by the EAPR process and was not showing under a toxic chemical stressing according to its total chlorophyll content and chlorophyll a/b ratio.

\section{ACKNOWLEDGEMENT}

Authors would like thank to KEMENRISTEKDIKTI, the Republic of Indonesia for financial support through Penelitian Terapan Unggulan Perguruan Tinggi (PTUPT) 2017 (Kontrak Penelitian: 041/HB-LIT/IV/2017; Surat Keputusan KEMENRISTEKDIKTI: 663/M/KP/IIX/2015). Furthermore, additional financial support from AIPT program 2016 of Universitas Islam Indonesia is gratefully acknowledged.

\section{REFERENCES}

[1] El-Fadel, M., Bou-Zeid, E., Chahine, W., and Alayli, B., 2002, Temporal variation of leachate quality from pre-sorted and baled municipal solid waste with high organic and moisture content, Waste Manage., 22 (3), 269-282.

[2] Christensen, T.H., 1992. "Attenuation of Leachate Pollutants in Groundwater" in Landfilling of Waste: Leachate, Christensen, T.H., Cossu, R., and Stegmann, R., Eds., Elsevier, Barking, UK, 441483.

[3] Environment Agency, 2003, Guidance on Monitoring of Landfill Leachate, Groundwater and Surface Water, London, UK.

[4] Monje-Ramirez, I., and Orta de Velásquez, M.T., 2004, Removal and transformation of recalcitrant organic matter from stabilized saline landfill leachates by coagulation-ozonation coupling processes, Water Res., 38 (9), 2358-2367.

[5] Zouboulis, A.I., Chai, X.L., and Katsoyiannis, I.A., 2004, The application of bioflocculant for the removal of humic acids from stabilized landfill leachates, J. Environ. Manage., 70 (1), 35-41.

[6] Kamenev, I., Pikkov, L., and Kallas, J., 2002, Aerobic bio-oxidation combined with ozonation in the treatment of landfill leachates, Proc. Est. Acad. Sci. Chem., 51(3), 148-155.

[7] Karrer, N.J., Ryhiner, G., and Heinzle, E., 1997, Applicability test for combined biological-chemical treatment of wastewaters containing biorefractory compounds, Water Res., 31 (5), 1013-1020.

[8] Renou, S., Givaudan, J.G., Poulain, S., Dirassouyan, F., and Moulin, P., 2008, Landfill leachate treatment: Review and opportunity, $J$. Hazard. Mater., 150 (3), 468-493. 
[9] Raskin, I., and Ensley, B.D., 2000, Phytoremediation of Toxic Metals: Using Plants to Clean Up the Environment, John Wiley \& Sons, Inc., New York, 304.

[10] Hodko, D., Hyfte, J.V., Denvir, A., and Magnuson, J.W., 2000, Methods for enchancing phytoextraction of contaminants from porous media using electrokinetic phenomena, US Patent, 6,145,244.

[11] O'connor, C.S., Lepp, N.W., Edwards, R., and Sunderland, G., 2003, The combined use of electrokinetic remediation and phytoremediation to deconteminate metal polluted soils: A laboratory scale feasibility study, Environ. Monit. Assess., 84 (1-2), 141-158.

[12] Putra, R.S., Ohkawa, Y., and Tanaka, S., 2013, Application of EAPR system on the removal of lead from sandy soil and uptake by Kentucky bluegrass (Poa pratensis L.), Sep. Purif. Technol., 102, 34-42.

[13] Bi, R., Schlaak, M., Siefert, E., Lord, R., and Connolly, H., 2010, Alternating current electric field effects on lecttuce (Lactuta sativa) growing in hydroponic culture with and without cadmium contamination, J. Appl. Electrochem., 40 (6), 12171223.

[14] Putra, R.S., Cahyana, F., and Novarita, D., 2015, Removal of lead and copper from contaminated water using EAPR system and uptake by water lettuce (Pistia stratiotes L), Procedia Chem., 14, 381-386.

[15] Putra, R.S., Trahadinata, G.A., Latif, A., and Solehudin, M., 2017, Wastewater treatment of chemical laboratory using electro assistedphytoremediation (EAPR), AIP Conf. Proc., 1823 (1), 020077.

[16] Moran, R., and Poranth, D., 1980, Chlorophyll determination in intact tissue using $N, N$ dimethylforamide, Plant Physiol., 65 (3), 478-479.

[17] Chakroun, H.K., Souissi, F., Bouchardon, J.L., Souissi, R., Moutte, J., Faure, O., Remon, E., and Abdeljaoued, S., 2010, Transfer and accumulation of lead, zinc, cadmium and copper in plants growing in abandoned mining-district are, Afr. J. Environ. Sci. Technol., 4 (10), 651-659.

[18] Dushenkov, V., Kumar, P.B., Motto, H., and Raskin, I., 1995, Rhizofiltration: The use of plants to remove heavy metals from aqueous streams, Environ. Sci. Technol., 29 (5), 1239-1245.

[19] Li, R., Guo, P., Baum, M., Grando, S., and Ceccarelli, S., 2006. Evaluation of chlorophyll content and fluorescence parameters as indicators of drought tolerance in barley, Agric. Sci. China, 5 (10), 751-757.

[20] Huang, J.W., Chen, J., Berti, W.R., and Cunningham S.D., 1997, Phytoremediation of lead-contaminated soils: role of synthetic chelates in lead phytoextraction, Environ. Sci. Technol., 31 (3), 800-805.

[21] Chantachon, S., Kruatrachue, M., Pokethitiyook, P., Upatham, S., Tantanasarit, S., and Soothornsarathool, V., 2004, Phytoextraction and accumulation of lead from contaminated soil by vetiver grass: laboratory and simulated field study, Water Air Soil Pollut., 154 (1-4), 37-55.

[22] Putra, R.S., Novarita, D., and Cahyana, F., 2016, Remediation of lead $(\mathrm{Pb})$ and copper (Cu) using water hyacinth [Eichornia crassipes (Mart.) Solms] with electro-assisted phytoremediation (EAPR), AIP Conf. Proc., 1744, 020052.

[23] Saiyood, A., Vangnai, A.S., Inthorn, D., and Thiravetyan, P., 2012, Treatment of total dissolved solids from plastic industrial effluent by halophytic plants, Water Air Soil Pollut., 223 (8), 4865-4873.

[24] King, D.L., 1970, The role of carbon in eutrophication, J. Water Pollut. Control Fed., 42 (12), 2035-2051.

[25] Huang, Y.R., Hung, Y.C., Hsu, S.Y., Huang, Y.W., and Hwang, D.F., 2008, Application of electrolyzed water in the food industry, Food Control, 19 (4), 329-345. 